\title{
ДІЯЛЬНІСТЬ ПРАВООХОРОННИХ ОРГАНІВ ЩОДО ЗМІЦНЕННЯ ПУБЛІЧНОЇ БЕЗПЕКИ ТА ПОРЯДКУ НА ЗАЛІЗНИЧНОМУ ТРАНСПОРТІ
}

Челпан О. В.

Одним із завдань держави $\epsilon$ створення умов для їх належної реалізації. Стаття 3 Конституції України визначає, що метою держави є забезпечення прав і свобод громадян. Для цього повинні бути створені певні політичні, економічні, ідеологічні умови. 3 огляду на різноманіття прав і свобод громадян, закріплених у Конституції України, вони реалізуються у певних сферах суспільного, економічного та політичного життя. Ці сфери не виступають ізольовано одна від одної, вони перетинаються, і тому в окремих випадках може скластися конгломерат суспільних відносин, що підпадають під вплив різного виду умов, що створюються для реалізації громадянами своїх прав і свобод. Таким конгломератом виступає публічна безпека та порядок, у сфері яких відбувається реалізація численної частини прав $і$ свобод або створюються передумови для їхньої реалізації. В Україні функціонує одна з найбільших у європі систем залізничного транспорту, яка найкоротшим наземним шляхом з'єӘнує євроатлантичний та азійськотихоокеанський регіони. Особливого значення набуває вирішення проблеми, що пов'язана із забезпеченням безперебійного функціонування залізничного транспорту, громадської безпеки на об'єктах пасажирської та вантажної інфраструктури залізниць. Саме у цій сфері важливе місце належить правоохоронним органам, зокрема Національній поліції, до компетенції яких належить охорона публічної безпеки та порядку. у статmі розглянуто питання про співвідношення понять «громадська безпека» та «громадський порядок». Проаналізовано нормативно-правовий складник цієї категорії. Обґрунтовано унормування законодавчої термінології шляхом внесення змін і доповнень до законодавства. Розглянуті питання щодо удосконалення організаційно-правових питань охорони публічної безпеки та порядку на залізничному транспорті. Встановлено, що ефективність охорони громадського порядку та забезпечення громадської безпеки на об'єктах залізничного транспорту прямо залежить від знань та умінь правильно сполучати форми тактики із загальноприйнятими засобами охорони громадського порядку та забезпечення громадської

(c) Челпан О. В., 2020 безпеки на об'єктах залізничного транспорту, що склалися у системі МВС України.

Ключові слова: публічна безпека, публічний порядок, громадська безпека, громадський порядок, залізничний транспорт, закон, порядок, взаємодія, нормативно-правовий акт.

Chelpan 0. V. Activity of the law enforcement bodies for improving the railway transport public security and order

One of the tasks of the state is to create conditions for their proper implementation. Article 3 of the Constitution of Ukraine stipulates that the purpose of the state is to ensure the rights and freedoms of citizens. To do this, certain political, economic and ideological conditions must be created. Given the diversity of rights and freedoms of citizens enshrined in the Constitution of Ukraine, they are implemented in certain areas of social, economic and political life. These areas do not act in isolation from each other, they intersect, and therefore in some cases may form a conglomeration of social relations, subject to various types of conditions created for the realization of citizens' rights and freedoms.

Such a conglomerate is public security and order, in the sphere of which the realization of numerous rights and freedoms takes place or the preconditions for their realization are created. Ukraine has one of the largest rail transport systems in Europe, connecting the Euro-Atlantic and Asia-Pacific regions by the shortest land route. Of particular importance is the solution of the problem associated with ensuring the smooth operation of railway transport, public safety at the facilities of passenger and freight infrastructure of railways. In this area, an important place belongs to law enforcement agencies, in particular the National Police, which is responsible for the protection of public safety and order. The article considers the question of the relationship between the concepts of "public safety" and "public order". The normative-legal component of this category is analyzed. Normalization of legislative terminology by making changes and additions to the legislation is substantiated. Considered issues related to the improvement of organizational and legal issues of public safety and order in railway transport. It is established that the effectiveness of public order protection and public safety at railway transport 
facilities directly depends on the knowledge and skills to correctly combine forms of tactics with conventional means of public order protection and public safety at railway transport facilities, which have developed in the Ministry of Internal Affairs of Ukraine.

Key words: public security, public order, social security, social order, railway transport, law, order, cooperation, regulatory act.

Одним із завдань держави $\epsilon$ створення умов для їх належної реалізації. Важлива роль під час реалізації завдань належить правоохоронним органам, особливо під час забезпечення надійного захисту прав та свобод громадян, власності, інтересів суспільства і держави, а також належної публічної безпеки та порядку у всіх сферах життєдіяльності людини. Належна діяльність правоохоронних органів сьогодні має важливе значення з огляду на складні умови становлення державності в Україні.

У сучасній юридичній науці проблеми громадського порядку висвітлені в наукових дослідженнях таких провідних вчених, як О.М. Бандурка, Д.М. Бахрах, Є.О. Безсмертний, Ю.П. Битяк, І.І. Веремеєнко, І.П. Голосніченко, Є.В. Додін, О.П. Коренєв, М.В. Корнієнко І.М. Пахомов, Л.Л. Попов, О.В. Серьогін, Х.П. Ярмакі та інших. Зусиллями цих науковців сформовано також основні положення стосовно адміністративно-правового статусу у сфері забезпечення громадського порядку та громадської безпеки, однак новації та реформи сьогодення потребують наукового дослідження як для науково-дослідної, так і для правозастосовної діяльності під час вивчення проблем щодо забезпечення публічної безпеки та порядку саме на залізничному транспорті.

Варто дослідити понятійній апарат, формулювання та наукове обґрунтування поняття «громадська безпека», а також встановимо певні зв'язки 3 іншими суміжними правовими явищам. Тому доцільно розглянути питання про співвідношення поняття «громадська безпека» із поняттям «громадський порядок».

Необхідно зауважити на певні складнощі у визначенні поняття «громадська безпека», яке з точки зору загальнометодологічного підходу має всі необхідні ознаки, які дозволяють віднести його до складних правових феноменів. Сьогодні трапляються випадки, коли науковці висловлюють критичні зауваження про те, що держава як провідний суб'єкт забезпечення громадської безпеки захищає щось неконкретне. Це пояснюється недостатнім науковим розробленням цього поняття, адже наразі бракує комплексних наукових дослі- джень, що були 6 присвячені проблемам гарантування громадської безпеки і за звичайних умов, і за умов виникнення надзвичайних ситуацій різного характеру. Важливе значення становить з'ясування наукової проблеми стосовно співвідношення понять «громадський порядок» $\mathbf{i}$ «громадська безпека» [1, с. 90].

Громадський порядок докладно досліджено в правознавстві, що доводиться значною кількістю наукових розробок із даного питання. Починаючи докладний аналіз понять «громадський порядок», «публічний порядок», «громадська безпека», «публічна безпека», зауважимо, що указані поняття дуже тісно пов'язані між собою, у зв'язку із чим у юридичній науці немає єдиного погляду на вирішення проблематики співвідношення громадського порядку і громадської безпеки. Учені вважають, що громадський порядок $\epsilon$ складовою частиною громадської безпеки [2, с. 23]. Схиляючись до цієї думки, варто наголосити, що гарантування громадської безпеки $\epsilon$ необхідним складником підтримання громадського порядку, натомість важливе значення для гарантування громадської безпеки має зміцнення громадського порядку.

Зазначене дає змогу дійти висновку, що поняття «публічна безпека» i «публічний порядок» не $\epsilon$ тотожними і дещо різняться за змістом. Тому, на нашу думку, публічний порядок передусім пов'язаний із публічною безпекою, яку покликані забезпечувати спеціальні органи виконавчої влади шляхом нагляду та застосування адміністративного примусу щодо осіб, які його порушують. Попри те, що публічний порядок і публічна безпека - це самостійні поняття, категорії, явища, між ними наявний тісний діалектичний взаємозв'язок. Так, недопущення масових безладів створює умови, що переважають можливе порушення публічної безпеки. Водночас неухильне виконання правил, які сприяють забезпеченню останньої, гарантує надійне забезпечення публічного порядку [7, с. 208].

Порушення публічної безпеки та порядку на залізничному транспорті, його експлуатації і правил руху мають підвищену громадську небезпеку і можуть призвести до тяжких наслідків, дезорганізації пасажирських і вантажних перевезень, завдати матеріальної шкоди, викликати аварії, катастрофи, спричинити нещасні випадки, запізнення потягів, літаків, річкових і морських суден. Тому громадський порядок і безпека на транспорті взагалі та на залізничному транспорті зокрема, мають особливо важливе значення, а їх забезпечення на належному рівні $\epsilon$ однією з головних завдань правоохоронних органів. 
За таких умов особливо гостро постають питання визначення та пошуку шляхів удосконалення організаційно-правових питань охорони публічної безпеки та порядку на залізничному транспорті. Сьогодні існує дуже багато прогалин у діючому нормативно-правовому забезпеченні щодо аналізу складових організаційно-правових елементів охорони публічної безпеки та порядку на залізничному транспорті, які негативно впливають на забезпечення на залізничному транспорті публічної безпеки та порядку.

Необхідно наголосити, що забезпечення ефективної охорони публічної безпеки та порядку на залізничному транспорті, надійний захист прав та свобод громадян, власності, інтересів суспільства і держави нерозривно пов'язано 3 необхідністю чітко налагодженої, побудованої на наукових засадах організації роботи всіх апаратів і підрозділів, їх взаємодії та дійсного співробітництва з громадськістю.

Стосовно діяльності правоохоронних органів по зміцненню публічної безпеки та порядку в його широкому розумінні, то одним із головних напрямів має стати створення гнучкої системи правоохоронних органів, здатної самостійно пристосовуватися до змін у суспільстві, його динаміки та структури [1, с. 7]. Виходячи з цього, охорона публічної безпеки та порядку виступає пріоритетним напрямом і основною частиною діяльності правоохоронних органів натепер.

Ефективність виконання завдань з охорони публічної безпеки та порядку на залізничному транспорті безпосередньо залежить від стану оперативної обстановки, яка склалась на конкретно взятій території в певних часових межах та від правильності обрання тактики управління силами та засобами.

Розглядаючи завдання щодо охорони публічної безпеки та порядку на залізничному транспорті, зазначимо такі:

а) забезпечення охорони публічної безпеки та порядку на транспортних магістралях, в рухомому складі та інших об'єктах транспорту;

б) попередження та припинення злочинів та інших правопорушень;

в) швидке і повне розслідування та розкриття злочинів, вжиття заходів щодо усунення причин та умов, які їм сприяють;

г) забезпечення охорони державної власності, захист прав і законних інтересів громадян, підприємств, установ і організацій від злочинних посягань та інших антигромадських дій.

Відповідно до зазначених завдань повинні виконуватися такі функції:
- забезпечення охорони публічної безпеки та порядку на дільницях обслуговування;

- здійснення у встановленому порядку нагляду за виконанням посадовими особами та громадянами рішень органів державної влади з питань охорони публічної безпеки та порядку під час користування залізничним транспортом;

- має проводитись робота щодо попередження та припинення злочинів, інших антигромадських дій, виявлятись причини та умови, які сприяють правопорушенням, вживають заходів до їх усунення;

- вести разом з іншими державними органами та громадськими організаціями боротьбу з пияцтвом і алкоголізмом, наркоманією, проституцією, бродяжництвом;

- здійснювати оперативно-розшукові заходи щодо встановлення джерел укриття доходів та ухилення від сплати податків підприємницькими структурами;

- організовувати боротьбу з крадіжками вантажів, злочинними посяганнями на особисту та майнову безпеку пасажирів, 3 рецидивною та груповою злочинністю, безпритульністю та правопорушеннями неповнолітніх на об'єктах залізничного транспорту;

- вживати згідно з законом заходи по заявам громадян і повідомленням посадових осіб про скоєні злочини або злочини, що готуються, у встановленому порядку;

- порушувати кримінальні справи та здійснювати у межах встановленої законом компетенції попереднє розслідування цих справ, забезпечувати підготовку матеріалів за протокольною формою;

- здійснювати оперативно-розшукові та інші передбачені законом заходи з метою виявлення злочинів і осіб, які їх скоїли, розшуку осіб, які переховуються від слідства та суду, пропали без вісті, встановлення осіб непізнаних трупів;

- виконувати рішення судів, постанови прокурорів і слідчих про привід осіб, котрі проживають на дільниці обслуговування, які ухиляються за їх викликом, виконувати постанови прокурорів і санкціоновані судом постанови слідчих про взяття під варту, прийняті у встановленому порядку постанови про адміністративний арешт, охороняють і конвоюють заарештованих та затриманих;

- здійснювати контроль за виконанням правил зберігання вогнепальної зброї та боєприпасів у підрозділах воєнізованої охорони;

- здійснювати нагляд за дотриманням установами, організаціями, посадовими особами та 
громадянами на дільниці обслуговування правил, нормативів і стандартів пожежної безпеки;

- вживати заходів щодо надання невідкладної допомоги особам, які потерпіли від катастрофи, аварій, правопорушень i нещасних випадків, а також тим, хто перебуває у безпомічному стані;

- розробляти і організовувати виконання спеціальних заходів за оперативними планами за надзвичайних обставин. У встановленому порядку здійснювати огляд багажу, ручної поклажі та особистий огляд пасажирів;

- вести прийом громадян, розглядати і вирішувати пропозиції, заяви та скарги з питань, які належать до їх компетенції;

- забезпечувати зберігання знайдених та зданих документів, цінностей та іншого майна, вживати заходів щодо повернення їх законним володарям, організовувати охорону державного, колективного та індивідуального майна громадян, що залишилось без нагляду.

Іншим важливим напрямом удосконалення спільної діяльності для забезпечення публічної безпеки та порядку $\epsilon$ вирішення проблем та активізація взаємодії структурних підрозділів та Національної поліції України, про що свідчить Наказ Міністерства внутрішніх справ України, Міністерства інфраструктури України 02 березня 2020 року № 204/175 «Про затвердження Порядку взаємодії органів (підрозділів) поліції з підрозділами акціонерного товариства «Українська залізниця» [3].

В цьому нормативно-правовому акті розглянуто напрями та форми взаємодії, але цього недостатHьо.

Взаємодія організовується за такими напрямами:

1) обмін інформацією, що стосується вчинених на об'єктах інфраструктури залізничного транспорту кримінальних та адміністративних правопорушень, випадків травмування або загибелі осіб та інших подій, пов'язаних з функціонуванням залізничного транспорту;

2) розроблення та здійснення узгоджених заходів, спрямованих на запобігання, виявлення та припинення правопорушень, учинених на об'єктах інфраструктури залізничного транспорту, захист власності від протиправних посягань, у тому числі вантажів, які перевозяться регіональними філіями;

3) узагальнення підсумків спільної роботи, проведення спільних нарад та робочих зустрічей.

Основними формами взаємодії $\epsilon$ :

1) надання інформації, що стосується вчинених на об'єктах інфраструктури залізничного транспорту кримінальних та адміністративних правопорушень або подій, у тому числі тих, які пов'язані з пошкодженням шляхів сполучення і транспортних засобів, блокування транспортних комунікацій, а також захоплення транспортного підприємства;

2) інформування за письмовими запитами підрозділів АТ «Укрзалізниця» про кримінальні та адміністративні правопорушення, учинені працівниками товариства, а також про результати розслідування (перевірки) фактів загибелі (травмування) осіб на залізничному транспорті;

3) проведення спільних нарад, робочих зустрічей з метою пошуку шляхів вирішення наявних проблем щодо протидії злочинності на об'єктах інфраструктури залізничного транспорту його безпечного функціонування, а також координації діяльності за цими напрямами роботи;

4) утворення, у разі потреби, спільних груп для проведення профілактичних заходів, спрямованих на запобігання вчиненню правопорушень, ужиття заходів з виявлення та припинення кримінальних правопорушень на об'єктах інфраструктури залізничного транспорту.

Варто зазначити, що ефективність виконання завдань з охорони публічної безпеки та порядку на залізничному транспорті безпосередньо залежить від стану оперативної обстановки, яка склалась на конкретно взятій території в певних часових межах та від правильності обрання тактики управління силами та засобами.

Таким чином, можна констатувати, що завданнями правоохоронної діяльності, яка представляє собою систему соціально-правових засобів, що забезпечують охорону правопорядку, $\epsilon$ не тільки боротьба з правопорушеннями шляхом залучення винних до відповідальності, але i підтримка, зміцнення правопорядку, створення сприятливих умов для дії правових приписів, безперешкодного здійснення суб'єктами їхніх прав і обов' язків [6, с. 85].

Специфічний характер злочинності на залізничному транспорті викликає потребу у внесенні детальних змін до нормативно-правового законодавства.

До того ж доцільним було б прийняття відомчого нормативного акту з питань такого роду взаємодії, де були б викладені: питання компетенції та повноважень посадових осіб в організації та координації взаємодії підрозділів та служб правоохоронних органів; завдання та мета взаємодії, іiї межі; процедурні питання розроблення спільного плану дій; визначення способів, засобів 
та прийомів взаємодії, зв'язку між учасниками, інформування суб'єкта координації; забезпечення сторін, що взаємодіють, необхідними матеріальними та іншими ресурсами; процедури контролю та моніторингу з питань функціонування елементів системи взаємодії тощо.

Також, враховуючи позитивний досвід забезпечення публічної безпеки та порядку у транспортній інфраструктурі країн ЄС, де органи поліції на транспорті в оперативному відношенні комплексно обслуговують усі види транспорту, які входять до національних транспортних систем, та беручи до уваги закон України «Про транспорт», який визначає Національну транспорту систему як єдину технологічну структуру, доцільно створити у системі МВС України окремий структурний підрозділ, завданням якого буде забезпечення правопорядку на усіх видах (залізничному, автомобільному, авіаційному, морському, річковому, трубопровідному) транспорту та забезпечить створення ефективних та дієвих механізмів з реалізації завдань з охорони громадського порядку та протидії злочинності тощо [4].

А тому безперечним $\epsilon$ те, що ефективність охорони громадського порядку та забезпечення громадської безпеки на об’єктах залізничного транспорту прямо залежить від знань та умінь правильно сполучати форми тактики із загальноприйнятими засобами охорони громадського порядку та забезпечення громадської безпеки на об'єктах залізничного транспорту, що склалися у системі МВС України.

\section{Література}

1. Курбанов Я.Л. Забезпечення громадського порядку та громадської безпеки за сучасних умов: питання теорії. Південноукраїнський правничий часопис. № 3-4. 2016. С. 90.

2. Ольховський Є.Б. Адміністративно-правові засоби забезпечення громадської безпеки : дис. ... канд. юр. наук, 12.00.07. Харків, 2003. 191 с.

3. Про затвердження Порядку взаємодії органів (підрозділів) поліції з підрозділами акціонерного товариства «Українська залізниця»: Наказ Міністерства внутрішніх справ України, Міністерства інфраструктури України 02 березня 2020 року № 204/175. URL: https://zakon.rada.gov.ua/laws/ show/z0386-20\#Text.

4. «Про транспорт» Закон України. Відомості Верховної Ради України (ВВР), 1994, № 51, ст. 446. URL: https://zakon.rada.gov.ua/laws/show/232/94\%D0\%B2\%D1\%80\#Text.

5. Закон України «Про Національну поліцію» від 02.07.2015 - BBP - № 580-VIII. URL: http:// zakon4.rada.gov.ua/laws/show/580-19].

6. Фатхутдінов В.Г. Частотність операціоналізації та контекстуальність використання терміна «публічна безпека» в Законі України «Про Національну поліцію України». URL: http://goalint.org/ chastotnist-operacionalizacii-takontekstualnistvikoristannyaterminu-publichna-bezpekav-zakoniukraini-pro-nacionalnu-policiyuukraini.

7. Крищенко А.Є. Особливості визначення терміна «публічна безпека і порядок». Науковий вісник Національної академії внутрішніх справ. № 1(102). 2017. С. 208.

Челпан О. В., здобувач кафедри кримінології та кримінального права Національної академії внутрішніх справ 